\title{
Modeling of Role-Behavior of Students-Translators in the Lessons on Professionally-Oriented Translation at Spanish Language Faculty
}

\author{
Imanova Elvira Mahammad $^{1}$ \\ ${ }^{1}$ Department of Spanish Translation, Azerbaijan University of Languages, Baku, Azerbaijan \\ Correspondences: Imanova Elvira Mahammad, Department of Spanish Translation, Azerbaijan University of \\ Languages, Baku, Azerbaijan. E-mail: shalalahaliyevah@yahoo.com; elvira060606@hotmail.com
}

Received: August 30, 2017 Accepted: November 8, 2017 Online Published: December 23, 2017

doi:10.5539/ijel.v8n2p279 URL: http://doi.org/10.5539/ijel.v8n2p279

\begin{abstract}
The article deals with role behavior of students-translators in professionally-oriented translation lessons. The task of the given article is to look through the samples of intensive teaching of professionally-oriented translation at translation faculties, which is based on the exercises of role behavior. Translation is known to be one of the difficult, debatable and interesting matters in a language. Main target of learning a foreign language is bilingual communication, but in the profession of translator bilingual communication can be called its essence. Modern role theory is based on the concept of George Herbert Mead. The other specialist-Morton Deutsch and Robert Krauss define the following aspects of roles:

- Role as a system of expectations, which exists in the society.

- Role as a system of specific expectations with respect of the individual to itself.

- Role as an open, observed behavior of an individual, occupying a definite position.

To the professionally-oriented translation we can refer the sequential (or consecutive) translation.

Role behavior exercises can be divided into two types:

The 1st type includes the exercises, which are used at first and which imply minimal lexical loading for students. The 2nd type includes exercises with role behavior, which is characterized by the complex vocabulary of professionally-oriented character. For the diversity of professionally-oriented lexics, theme of the exercises with role behavior can be changed and extracurricular practice can be organized. For example, these can include situations on the excursion to a museum.

The following authors devoted their works to this matter: Christine Durieux, Pérez Gamero, Hurtado Albir, Borrás Espasa, Gonzales Davies. All of them have the same viewpoint that for the beginning translator should know the theme of translation and specifics of professionally-oriented translation, possess extra knowledge and gather information rightly.
\end{abstract}

Keywords: role behaviors, professionally-oriented lexics, increase in motivation, organization and methods of teaching of translation, communicative competence

\section{Introduction}

Today the development of multilateral relations among our country and other countries lead to the increase in the demand in translators in different spheres. However, compared with European system of education, in the preparation of students-translators at Azerbaijan University of Languages, there is no division of them (translators) according to different specialties; moreover, there is no thematic division of students-translators with different diplomas. In the diplomas there is only one specialty fixed, i.e., "translator". In connection with this, the target of High School of our country is comprehensive and diverse preparation of translators, who, in the future, can satisfy the needs of the customer not depending on the theme and type of the translation. This fact makes the process of teaching translation in our country much richer and at the same time, more difficult. A translator has double responsibility here: firstly, he must organize the lessons on translation correctly, and, secondly, correctly work out teaching plan, which lead to the development and mastering the translator's competence, which are relevant to both an interpreter and also a translator. We should note one fact that, if after graduating from university, an English language translator can afford to choose a subject or a profile, where he 
wants to work, then the matter with Spanish language translators is quite different, because of the limitations in demand for the translation from this language Spanish language translators cannot afford such kind of limitation. That's why they must maximally demonstrate their efforts in the process of teaching, in order to remain in this sphere.

\section{Research Methodology}

All the investigations are held with the help of investigation methods, and all the methods should be chosen in connection with the topic investigated. The appropriate choice of methods guarantees the objective results of the investigation.

In the investigation process of the given topic we have used the following methods: synchronic method, descriptive method, observation method, linguistic analysis method.

\section{Didactics of Translation}

Organization and methods of teaching translation is obviously and indirectly conditioned with the acceptance of a number of initial postulates. We will look through these postulates within the framework of teaching translation on the basis of the application of the exercises on role behavior, which will be described in the future (Calvo Encinas, 2012).

1). Translation is regarded as a complex and many-sided kind of mental activity, which can pursue different aims, can be carried out in different conditions, by means of different ways and under the influence of many factors.

Students-translators make sure of the complexity and many-sidedness of the given mental activity completely only after beginning the 3 rd course, when they get acquainted with professionally-oriented translation and many numerous terms, new words, special phraseology and so on. The professionally-oriented translation may include: medical translation, juridical translation, translation of materials related to oil-gas sphere, economical translation. Realization of oral and written translation and their subdivisions are used in the capacity of the target acts. For creating different conditions of realization of the process of translation, the teacher should have his/her imagination worked in order to model correctly the knowledge, which must be maximum close to real conditions and situations (14). Speaking of the factors, which can affect the realization of the translation process, we should note psychological condition of students, and if a students is in bad mood just for some reasons, so, it influences negatively the concentration of his attention, his memory and consequently the translation.

2). Like all types of activity, translation demands, for its realization, definite knowledge, ability (conscious implementation of definite operations) and skills (semiautomatic and automatic implementation of definite actions), which must be created in the process of teaching.

Of course, during all the time of teaching of translation, students get necessary on the theory of translation, and consciousness and making semi-automaticness and automaticness of skills and ability can be created owing to the application of the exercises on role behavior. Simple learning and learning by heart new words is not equal to that effectiveness, which is obtained by using them practically (Bogomolova, 2001).

3). Translation activity can be realized by the translator consciously (as a result of the analysis and reasonable results) or by intuition. Correlation of conscious and intuitive varies in different translators and in translating different texts and in different conditions. The ability to realize conscious and intuitive translation activities (translator competence) can be improved in the process of teaching and practical part.

It should be noted that conscious translation is mostly specific for written translation, when a translator, having got the original text before and enough time for its complete analysis, consciously and deliberately chooses the translation for this or that word as opposed to an interpreter, who very often can determine, by the help of his intuition, how the further communication will develop.

However, in the process of preparation of the students-translators by the help of the exercises of role behavior oral translation becomes, conscious sand intuitive to the extent of mastering skills. At the initial stage of the use of exercises of role behavior students-translators realize conscious translation, as they are aware of the theme of the translation and they have even ready material in mother tongue in a foreign language. From time to time, for the development of the intuitive quality on translating, a teacher doesn't present any information, but does this only before the beginning of the lesson, so, students-translators only intuitively can guess the lexics (vocabulary) of the text.

4). Realization of the translation competence happens at the presence of all language personality of the translator. It presupposes the availability of comprehensive cognitive and linguistic cognitions, large culture-wide erudition, necessary psychological qualities and literary-eloquential abilities in it. 
5). The aim of the teaching translation is not to acquire any norms, rules and receipts, which the translator can use automatically in all cases, but is the acquisition of principles, methods and ways of translation and the ability to choose and apply them differently in concrete conditions, to different texts and for different purposes. Particular matters, solved by the translator in the process of translation, can be typical, allowing to use a famous way or mode of solution, and can be individual, demanding new solution on the basis of principles of translation strategy and taking into account the peculiarities of the context and situation. The search of solution also includes results on the possibility of using famous way or mode of solution about the necessity of its modification or rejection from the typical one for benefit of the unique, occasional one.

Just during practical lessons on visual samples and situations which are maximum close to reality, students-translators can apply that theoretical basis, which they have acquired for the last 2 years of studying translation. Of course, the ability of the students-translators to feel that moment, when it is necessary to reject the typical solution and apply occasional one, demands him many practice on the basis of collaboration of the teacher and students, where teacher, all the time, must give interest to the speculation on the choice of appropriate decision, show the right direction and as appropriate, must direct, but the students must be ready to the conduct of such speculations.

6). The object of the translation activity is the information in the initial text. The plot of the text (message) represents semantically and formally finished whole, separate parts of which are correlated, but are not equally significant for the communication. The correlation of the whole to its parts is differently distinguished in the process of translation: depending on the type of the translation and its aim. It is possible more exact and complete reproduction of separate elements of the text in translation, if they become more or less important. In this sense, the whole can be (or cannot be) relatively more important than its parts.

Just in the practice students-translators understand, which parts of the original text are important for the continuation of the communication. Unconsciously omitting unimportant part of the original text in translation, they themselves see the illogicality and incompleteness of the communication. Or, vice-versa, they can feel which part of the original text doesn't contain any extra information.

7). Lingual units, making the text, are not the objects of translation. However, through them, the content of the text and the presence of definite lingual means are of semantic importance and can determine the character of translation matters and create difficulties for translation. In this sense there is a problem of transferring the meaning of lingual units while translation as a part of global content of the text. Professionally-oriented translation is characterized, firstly, by the problems arising in students while translating semantic elements. However, with the acquisition of knowledge about semantics in this sphere of translation on the basis of practical knowledge, less and less the cases, when any word can become the cause of incorrect transference of the content of the original text, arise.

8). Denoted correlation determines also the character of teaching materials, used in teaching translation. In the first place, these are the texts of different type, allowing to make educational translation close to the terms of a professional translator's work. In addition to that separate parts of a text and utterances are used in educational purposes, allowing to mark out typical translation difficulties and problems minimally in a necessary context.

None other than application of the exercises of role behavior allow to use texts of different themes of professionally-oriented character, and just this maximum brings students closer to real working conditions of professional translator.

9). In the process of teaching translation not only the ways of translation of the used teaching material should be learned, but also the methods of the solution of typical translation mattes and the strategy of the search of individual creative solutions. In this sense teaching of translation presupposes the ability to mark out in the teaching material typical translation matters and formulate common principles and particular means of their solution. Io different types of translation, general principles and means as well as specific methods can be applied to every type.

One cannot but agree with this judgment. While applying the role behavior having general character, students-translators use standard solutions of translation problems, but from the beginning of the application of more professionally-oriented role behavior, they arm with methods of translation, corresponding to every element of professionally-oriented text.

10). The character of interlingual communication predetermines principal multiplicity of variants of translation in the same pieces of the original. In connection with it in the process of teaching, students' attention is not brought to the issue of creating single correct (or optimal) translation of the supposed text. In addition to that the 
process of teaching includes critical estimation of teaching translations and deviation of inadmissible variants. Teachers' task includes probative demonstration of unacceptability, relying on comparative-semantic, contextual, linguo-cultural and stylistic analysis of the texts in the original and in translation. Such kind of analysis supposes the students' acquirement of necessary terms and notions of translation-studies and linguistics. Students get this knowledge while learning appropriate theoretical disciplines and the determined gaps in their knowledge are filled with the comments of teachers at lessons on translation.

A teacher realizes all these kinds of analysis indirectly with students before the use of the exercises with role behavior (one can see in the examples given below) as well as the joint discussion of results of such exercises (Grupo, 2001).

The main purpose of translation didactics is getting translator's competence by students. The use of below-given exercises during lessons on translation may be rendered to a group type of exercises, which, according to a whole group of authors devoting their articles to this topic, lead to the development of the following qualities in students:

- development of strategic competence in students, by the help of which he organizes his job effectively (division of responsibility and exercises, taking decisions, ability of being a leader);

- development of the ability to the adaptation to the demands of different types of translation in students;

- development of self-criticism in students while correcting and doing their jobs;

- development of the ability to gather information electronically in students;

- to enlarge knowledge connected with their profession in students;

- development of the ability in students to the professional communication and interaction within the framework of working group;

- visually to show to the student the positive and negative sides in the group (Komissarov, 2002).

\section{Discussions on the Topic}

At present, there are some debates in connection with the negative and positive features of the Soviet education system, particularly in teaching translation. Undoubtedly, it had positive qualities, otherwise the world wouldn't have known the great Soviet translators, but its negative sides should be taken into consideration, too. During the Soviet time, the process of teaching translation had several negative sides, one of which was unequal division of roles between teaches and students. It meant that "the main" in the process of teaching was a teacher, but a student had to accept his decisions without any rejection. The present education system has a policy, in which the main role belongs to a student, but a teacher acts as a "guide", who not only educates students, but also helps in different means and methods of correct orientation of students, taking into consideration their view-points. According to Natalya Dmitryevna Galskova, a number of investigations are held on optimal development of linguistic abilities of students, on the basis of which the quality of mastering foreign languages rises (Galskova, 2003). The results of the investigation allows to come to such a conclusion: the more features and peculiarities of a personality taught is taken into consideration, the more successfully the process of mastering communicative competence by learners goes on (Komissarov, 2002). Together with this, accounting of individual-psychological features doesn't assume "the adaptation" of teaching process to the possibility of every pupil under the influence of, in a special way, the organized teaching. For this reason, the exercises of role-behavior completely correspond to the present queries of the education system, as in such exercises, the students act as main participants, independently get necessary information, in selecting topics for translation their opinions are taken into consideration, sessions are held not in the format of simply reading sentences in the translation language followed by its translation - traditional method of teaching translation, but with visual presentation of the real situation. If to address to the literature on the application of exercises with role-behavior, so, it can be noticed that, it is mainly directed to the secondary school education and for this reason, it has considerably simplified variant. The aim of the conducted experiment with the application of these exercises is to use the given exercises with the students-translators, whose level of knowing a foreign language is comparatively higher than all the structures of a language. It would be appropriate to look through the theory on which these exercises are based.

Modern role theory is based on the concept of George Herbert Mead, who introduced this term in social psychology for the first time (Nunan, 1991). He used this term, while developing the idea of "accepting the role of the other one" in order to explain the act of interaction of individuals in the process of speech communication. According to Mead, the main term of the realization of the act of interaction, in our case it is bilingual communication, is capability to look at yourself from an outsider's viewpoint or with the eyes 
of the partner - the accepting the role of the other one. In the lessons of professionally-oriented translation, it is possible to apply exactly the theory of Mead: students-translators "try different social roles with the aim of exchanging them in the future, can compare how well and badly this or that student played his role, and most of all among all the role players, we will be interested in the role of the translator, as the main aim of carrying out all the exercises is connected with the role behavior and also the role, which is responsible for the successful realization of the given bilingual communication.

Morton Deutsch and Robert Krauss define the following aspects of roles: (Nunan, 1991).

1). Role as a system of expectations, which exists in the society, with respect to the behavior of an individual, occupying a definite position, and its interaction with other individuals.

While practicing role behavior, students-translators abstract away from their real social roles and take temporary roles and adequate behaviors to these roles. And if to accept a group of students as a mini society, so, in this society every individual gets into interaction with other individuals, though at the first stage they don't have marked system of expectations with respect to the behavior of one another, however, this system of expectations is obtained with the lapse of time.

2). Role as a system of specific expectations with respect of the individual to itself, who occupies a definite position, i.e., how he imagines the model of his own behavior in interconnection with other individuals. On finishing exercises of role behavior, the stage of discussions begins, when the student itself, and then together with other participants compare their ideas about the performance of their roles, which they had till the beginning of the exercises with that results, which were achieved after finishing these exercises (Dörnyei, 2008).

3). Role as an open, observed behavior of an individual, occupying a definite position.

The main aim of the use of exercises with role behavior in lessons on professionally-oriented translation is to observe the behavior of the students-translators how successfully or unsuccessfully they play the roles given to them, and a teacher plays an active role of observer.

Main target of learning a foreign language is bilingual communication, but in the profession of translator bilingual communication can be called its essence (Komissarov, 2002). In Latishev's book "Technology of translation" processes of monolingual and bilingual communication processes are described in details and schematically (Latishev, 2000).

The essence of bilingual communication is that sender should get the reaction from the addressee, which is the same with one in the monolingual communication. The addressee possesses the peculiarities, which define his reaction to the text:

- his communicative needs,

- his communicative competence (abbr. CC)

Communicative needs of the addressee are his attitude to the communication, defined by his intension to participate in it, and also by what he expects from them.

Communicative competence of the addressee is the totality of ability, skill and knowledge, which define his capability to accept and interpret the text adequately. Applying the methods of use of role behavior in lessons on professionally-oriented translation, we look through the students as final addressees, developing communicative competence in them for adequate perception of the translated text and as an addressees-translators, because, not having the experience in the given profession and enough extra linguistic knowledge, they often have problems in right perception and interpretation of an original text (Latishev, 2000).

The examples of role behavior, which will be given below can facilitate the acquisition and improvement of all these qualities in students-translators. It is necessary to dwell on the psychological and eloquential qualities of the students-translators, who can become an obstacle in the process of teaching.

In each group there is a student or students, who, because of their shyness, are not able to translate orally in the presence of their group-mates, as a result of shyness they have problems with the concentration of attention and the process of memorizing the text in the original. However, there is another group of students, who dislike talking in general, in contrast to those, who can talk in any topic, can be called orators. For overcoming all these problems from the students' viewpoint, a teacher, during the organization of the lessons for a start, gives them a passive role, so preparing them to a more active role in the exercises with role behavior.

\section{Motivation is One of the Main Terms at Translation Lessons}

Not depending on the faculty, the correct methodological organization of lessons at High Schools plays an 
important role, firstly, for increasing the motivation of students. From the motivation factor emerges complete and long-term assimilation of the learned material. If the student gives his attention to the given material with great enthusiasm and interest, so, this becomes the direct way to his long-term memory (Nord, 1991).

At translation faculty the students have a lot of subjects on translation, of course, they differ from each-other for their theme and the methods of translation, however, the essence is the same- this is translation, which is a very complicated thinking process, happening in the head of a translator, and which can be observed.

Because of such work load, a student, who has no experience of work in this sphere, gets tired or exhausted soon, and as a result of it, his motivation for doing translation in the next lesson goes down. Just for this reason, a teacher must always dwell upon how to organize sessions so that the increase in motivation could be proportional to the maximum acquisition of the material, and students couldn't feel physical and mental loading. As Zöltan Dörnyei notices, continual diversity of exercises doesn't lead to the increase in motivation of learners, especially if these exercises are uninteresting. In most cases teachers use ready material or manuals, and they cannot have time to use new assignments. The author suggests several motivation aspects when planning exercises:

Temptation: students get always interested in the assignments in which they must solve the problem, overcome some obstacles, and find out hidden information and so on.

Interesting content: with the easiest way of attracting the student's attention is giving them topics, which are connected with the things that interest students.

The novelty of the element: if any part or the whole exercise is new for students, so, it will result in the increase in motivation.

Intriguing element: exercises, which have contrary, paradoxical, problematic meaning lead to the emergence of curiosity in students.

Exotic elements: everybody likes to learn the places or personalities, which or who are different from one another.

Elements of fiction (or fantastic elements): exercises may lead to the development of fantasy in students while creating stories or playing the role of any hero.

Personal elements: many exercises may be stimulating if equate them with the students themselves, i.e., to associate the exercises with the life of the student himself.

Competition: the exercises, in the implementation of which students get something as an award, always attract them (Dörnyei, 2008).

Though the author offers to take into consideration the criteria presented by the teachers of foreign languages, the experience shows that at the lessons on translation they can be applied and even lead to desired results.

\section{Exercises with Role-behavior}

\subsection{Where to Use the Exercises with Role-behavior}

In the conducted experiment, the exercises with role-behavior were used at the lessons on sequential (or consecutive) translation, which, in general, consisted of 90 classroom hours. To the professionally-oriented translation we can refer the sequential (or consecutive) translation, though study program of AUL makes no provisions of the definite directivity of this subject. Here, just teachers gives directivity in concordance with the general level of the group, as in the used model all the students of the group took part (at the initial stage, some roles can have passive character, but with the lapse of time teacher must bring all the students into play).

The notion of professionally-oriented translation should be defined. Professionally-oriented translation implies the translation of special texts. Professionally-oriented text is a text, created by scientific disciplines (experimental, exact, humanitarian, economic juridical), technical (engineering, construction, communication) and specific spheres of activity (sport, commerce, finance). All these spheres create corresponding texts, which differ from the general ones, created in non-professional conditions, and which are directed to ordinary audience. There are two concepts of professional-orientation:

a) Professional-orientation for its subjects;

b) Professional-orientation for special characteristics with which there happens the exchange of information (Nunan, 1991). 


\subsection{Essence of Exercises with Role-behavior}

Role behavior exercises were divided into two types:

The first type includes the exercises, which were used at first and which implied minimal lexical loading for students. Let's see some examples of types of exercises with role behavior, which were used in the 3rd year of the translation faculty, at the Department of the Spanish language Translation of Azerbaijan University of Languages. In our case, as an interview, which implies minimal lexical loading, the interview with a famous writer has been used. Among the students (depending on the wish of the students) there was chosen a journalist, a writer and a translator. Before the interview, each hero was given an appropriate material, i.e., the questions of the journalist, the answers of the writer, and reading their texts, they marked out unknown words for themselves, found their translation, so that translator could get acquainted with unknown lexics, and then the interview began. For bringing the other students into play and for attracting their attention they were given a role of spectators, who at the end of the interview had to ask the writer questions, arising during the interview. In the beginning, small interviews were picked in order during one lesson students could change roles, so that each student might play the role of a translator, a journalist and a writer.

By getting skills, ability and necessary competence, exercises with role behavior of the 2nd type, which is characterized by the complex vocabulary of professionally-oriented character began to be used. The example for this was the situation from the sitting of the court, where all the students took an active part. However, for the beginning there should have been held (introductory) familiarization lesson, as students didn't have extensive knowledge about court system of the both countries. Two videos of real court sittings were shown in Russian, which is the mother tongue of the student-translator, and another video was in Spanish, which they learn to translate. After watching it, new terms and words, special phraseology in mother tongue and their equivalents in a foreign language were marked out. At home, students had to find out the meaning of professionally-oriented lexics. The differences and similarities of court systems of the both countries were discussed. After such analysis, translation began, every student knew the text of his role and the essence of the role performed.

\subsection{Some Nuances on Doing Exercises}

- As it was already mentioned, in the first lessons "journalist" and "writer" were given the questions and answers prepared beforehand, and in the following lessons students had to spontaneously think about the questions and answers, as they already possessed information about the structure of the interview (13).

- For increasing motivation and facilitation of translation, the first interview was held with the "writer", whom the students themselves chose. Teacher beforehand asked the students about the preferred writer and on this basis, he/she prepared material. Besides writers there were other famous people, such as, a football coach. If the hero of the interview was unfamiliar to the students, so the material was given to that hero, but a journalist himself was guided with the questions depending on the information obtained from the "hero".

There are notes in connection with the exercises of the 2nd type.

- At the first stages, these roles were divided on the choice of the students, these were the roles of a judge, an advocate, a prosecutor, the accused, the witnesses and of course the translator.

- Court sitting was held in Russian, i.e., in the mother tongue for the students, but, here the translator was loaded, so, if the rest of the students had to learn only the text in mother tongue, the translator had to learn and translate the original text.

It should be noted, the application of the exercises with role behavior at the lessons on sequential (or consecutive) translation should begin in the middle the term, as in the beginning students get acquainted with the subject, learn its difference from the other types of translation and get skills necessary for this type of translation, such as shorthand. Of course, the period of application of this method depends on the group level. In that case if teacher sees that learning shorthand takes much more time, he can prolong the application of role behavior or overlap these practical exercises.

By getting experience the division of roles occurred according to the choice of the teacher, and the theme of the court sitting changed: there were sittings on crime, family and administrative problems (Alekseyeva, 2004).

For the diversity of professionally-oriented lexics, theme of the exercises with role behavior can be changed and extracurricular practice can be organized. These can include situations on the excursion to a museum. In this case it is necessary to follow the same scheme of preparation, i.e., it is possible to choose one student, who will play the role of the translator and a second student for playing the role of the guide, and the rest of the students will be tourists, who can ask questions. During the following lessons the distribution of the roles will occur 
spontaneously. In this case, such kind of practice of translation will allow the students to simultaneously enlarge their extra linguistic knowledge and professionally-oriented lexics by visual demonstration in the sphere of history and culture.

\subsection{Results of the Application of the Exercises with Role-behavior}

The results, which were obtained after the application of the exercises with role-behavior, were positive, and they reflected not only the effectiveness of such didactics, but also the improvement of general psychological condition of the group (García, 2001).

- By the help of the exercises of role behavior, the students considerably enlarged their vocabulary, referring to professional lexics.

- Students-translators getting extra linguistic knowledge, necessary for this profession, played different social roles, and thus, got directly acquainted with different social behaviors personally.

- Just in practice, which is maximum close to reality, students-translators trained their ability of cursive writing (shorthand) — an inalienable ability of every oral translator.

- Performing different social roles, students-translators "compulsorily" (teacher lets the students know beforehand, that at the lessons all the students will take part, for which they will be given appropriate marks) got into communication with one another, getting communicative competence by this, and overcame the conflicts existing until that time in the group, since the group, in which the experiment with the application of the exercises with role-behavior was held, differed for their interpersonal relations. Just basing on interpersonal relations among the students, the whole group was divided into "subgroups", i.e., a group consisting of 10 students was subdivided into: one girl-student indivudum and she communicated with everybody, but didn't have a close friend, a boy-student indivudum - he also communicated with everybody without having a close friend, two students - close friends and three couple of students - close girl-friends. At the beginning of the experiment, they expressed no intention of participating at the general task, as they were accustomed to individual work. However, depending on the involvement in joint work, they supported each-other, they also worried about the correct performance of the role by another student.

\section{Concluding Remarks}

There are not many books dealing with the organization of the lessons on professionally-oriented translation. As an example we can note the names of some authors, who devoted their works to this matter: Christine Durieux, Pérez Gamero, Hurtado Albir, Borrás Espasa, Gonzales Davies (Álvarez, 2012).

All the authors have the same viewpoint that for the beginning translator should know the theme of translation and specifics of professionally-oriented translation up to the payment of the job done, should possess extra knowledge and gather information rightly. The teacher should use texts for translation with gradual complication.

In conclusion, we should note that obtained skills and abilities for translating professionally-oriented texts are considered to be a very complex process, demanding the same responsibility from the teacher as well as the student. In case of not discharging the responsibilities one of the sides will get the process of learning, and negative sides will not get desired results. The exercises with role behavior conducted by us imply to involve both sides into the process of teaching, where students play an active role, but the teacher does a passive one. It is possible that the described exercises should demand improvements. The teacher can include these corrections while doing these exercises, but in the process he must not reject the proposal of the students, who, being interested in the implementation of such kind of lessons, can show more creativeness than the teacher himself/herself.

\section{References}

Алексеева, И. С. (2004). Введение в переводоведение. Москва. (Alekseyeva, I. S., 2004). Introduction to translation study. Moscow).

Álvarez, S. (2012). Traducción: diseño de un curso de traducción económica en modalidad mixta (presencial-virtual) y su experimentación en el aula”. Spain.

Богомолова, Н. Н., \& Петровская, Л. А. (2001). Зарубежная соџиальная психология ХХ столетия. Теоретические подходы. Москва. (Bogomolova, N. N. \& Petrovskaya, L. A., 2001). Foreign social psychology of XX c. Theoretical approaches. Moscow).

Calvo, E. E., Jimenez, C. N., Mendoza, G. I., Moron, M. M., \& Ponce, M. N. (2012). Article "El trabajo colaborativo en la clase de traducción. Un caso práctico". España. 
Dörnyei, Z. (2008). Estrategias de motivación en el aula de lenguas. Barselona.

García, C. G., \& Yerba, V. G. (2001). Manual de documentación y terminología para la traducción especializada. Madrid.

Grupo PACTE. (2001). La competencia traductora y su adquisición. Revista de traducción 6, Spain.

http://dictionary2.com/ushakov/page/jelokvencija.php

http://ru.scribd.com/doc/141216525/Defining-Translation-Functions-the-Translation-Brief-as-a-Guideline-for-th e-Trainee-Translation

https://cyberleninka.ru/article/n/kognitivnye-osobennosti-perevoda-nauchno-tehnicheskogo-teksta

Гальскова, Н. Д. (2003). Современная методика обучения иностранным языкам. Москва. (Galskova N.D. (2003). Modern methods of teaching foreign languages. Moscow).

Комиссаров, В. Н. (2002). Современное переводоведение. Москва. (Komissarov, V. N., 2002). Modern translation study. Moscow).

Латышев, Л. К. (2000). Технология перевода. Москва. (Latishev, L. K., 2000). Technology of translation. Moscow).

Nord, C. (1991). Defining Translation Functions. The translation brief as a guideline for the trainee translator // Scribd. pp. 41-55.

Nunan, D. (1991). Language teaching methodology. Cambridge: Cambridge University Press.

\section{Copyrights}

Copyright for this article is retained by the author(s), with first publication rights granted to the journal.

This is an open-access article distributed under the terms and conditions of the Creative Commons Attribution license (http://creativecommons.org/licenses/by/4.0/). 